\title{
Keberadaan Radio Komunitas sebagai Eskalasi Demokratisasi Komunikasi pada Komunitas Pedesaan di Jawa Barat
}

\author{
Atie Rachmiatie \\ ABSTRACT \\ The main problem researched in this thesis was the existence of community radios in villages, \\ that was about the roles of function of them correlated with the escalation of democratization \\ in communication. The research was conducted in two Kecamatans that had different \\ characteristics, that was Kecamatan Cisewu which was minim in any information \\ exposure and geographically closed (blank spot) and Kecamatan Wanayasa which was relatively \\ open to access any information. The theory used to study the problem were Habermas \\ Communicative society theory and Uses and Dependency theory. The theory explained the \\ correlation between social system and communication media system at a community. \\ The democratization of communication was explained by Communitarianism Democracy \\ Theory - Tehranian. The research method used was qualitative method with etnography \\ communication. Data were collected through depth interview and focus group discussion. \\ The key informan woman were formal and informal social leaders and the person who managed \\ community radios. Focus group discussion was conducted to group of women, men, youths, \\ and others ot both of kecamatans. Analysis of etnography of communication try to explore \\ the native language, that was sundanese, used by the member of community, wether with or \\ without community media. The result of the research is accordance with research question. \\ The availability contribute awwarness about communication and information right \\ for the community members. The public community process through radio community \\ is the implementation of the daily public behaviour pattern of the community. \\ The process of democratization communication run slower in the closed area, \\ yet it is more dynamic in the opened area.
}

Kata kunci: radio komunitas, demokratisasi komunikasi, komunitas pedesaan

\section{Pendahuluan}

\subsection{Latar Belakang Penelitian}

Kecenderungan masyarakat Indonesia, dalam perspektif komunikasi, khususnya di daerah, masih tradisional, belum demokratis serta bersifat linier dengan arus informasi dari "atas ke bawah" (top down). Fenomena ini didukung oleh penelitian Badan Informasi dan Komunikasi Nasional (2000) bahwa, "kategori kelompok khalayak massa (heterogen dan anonim) menunjukkan karakteristik pasif, dalam arti hanya sebagai penerima, mengonsumsi informasi dengan kualitas dan kuantitas rendah. Kuantitas rendah berarti media komunikasi yang digunakan terbatas; dalam hal kualitas dengan indikator dari penggunaan isi (content) media, juga menunjukkan tingkat yang rendah" (BIKN, $2000: 137-146)$. 
Komunikasi yang demokratis dibutuhkan oleh seluruh bangsa di dunia yang punya komitmen tentang kesetaraan, keadilan, dan menjunjung tinggi hak asasi manusia, oleh karena hak untuk berkomunikasi dan memperoleh informasi merupakan salah satu bagiannya. Dengan adanya komunikasi yang demokratis antara berbagai kelompok, dengan hirarki yang berbeda atau golongan yang berlainan, dominasi antara yang satu atas yang lainnya dapat dieliminasi, serta kekuasaan dapat terkontrol.

Bila melihat realitas dari keseluruhan komponen yang terlibat dalam proses komunikasi: sumber, pesan, media, khalayak dan feedback, tampak ada "ketimpangan" komunikasi antara kaum elit-nonelit, antara pusat-daerah, atau kota-desa. Saat ini yang terkena terpaan revolusi komunikasi baru sebatas sekelompok kecil masyarakat perkotaan sebagai sasaran, media dan salurannya saja, seperti penggunaan $C D-R O M$, internet, televisi kabel teletex dan sejenisnya.

Jika mulai menelusuri komponen "sumber informasi" atau komunikator, tampaknya belum mengalami perubahan mendasar.

Dalam skala global sumber informasi masih diwarnai oleh liputan kantor berita atau production house negara-negara maju. Dalam skala nasional, informasi masih bersumber dari kaum elit, selebritis, pemerintah, penduduk kota besar, pengusaha, dan kaum bisnis yang kaya-raya. Suara warga masyarakat umum, penduduk desa, rakyat, kaum miskin jarang diekspos kecuali ketika mereka ada musibah bencana alam, kelaparan, atau mendapat bantuan dari luar negeri. Mayoritas penduduk Indonesia kurang memahami hak dan kewajibannya di bidang komunikasi, dan informasi. Hak informasi masyarakat, adalah hak untuk mencari, menggunakan, membuat, dan menyebarluaskan secara bebas informasi apa pun yang diinginkan dalam sebuah ruang publik yang terbuka, di mana setiap orang punya kedudukan yang setara. Inilah yang akan menuju pada demokratisasi komunikasi.

Istilah "demokratisasi komunikasi" memang relatif baru, dan sulit untuk mengukur dan membatasi secara tegas dengan demokrasi dalam aspek kehidupan sehari-hari yang lain seperti politik, sosial, ekonomi, pendidikan, hukum. Oleh karena, seperti dikemukakan oleh para pakar, karakteristik komunikasi adalah omnipresent atau ada di mana-mana. Theodorson (1969) juga berpendapat bahwa, “... Walaupun demokrasi pada dasarnya suatu konsep politik, tetapi dipergunakan juga dalam pengertian filosofis untuk menunjukkan suatu yang melekat erat (inherent) mengenai persamaan, kebebasan untuk mendapatkan manfaat, dan hak-hak azasi manusia." (Pelly \& Menanti, 1994 : 118).

Demokratisasi dalam kehidupan budaya tradisional sangat diperlukan guna mendorong dan memacu masing-masing daerah atau kelompok etnis memberikan andil bagi pengembangan kebudayaan nasional. Proses demokratisasi ini akan menumbuhkan suasana gairah, semangat kompetitif yang terbuka dan saling mengisi. Suasana ini pada gilirannya akan mendorong perubahan sosial-budaya secara menyeluruh.

Undang Undang Penyiaran Nomor 32 Tahun 2002 menjelaskan pentingnya fungsi media komunitas bagi bangsa, yaitu, "Untuk menjaga integrasi nasional, kemajemukan masyarakat Indonesia dan terlaksananya otonomi daerah, maka perlu dibentuk sistem penyiaran yang menjamin terciptanya tatanan informasi nasional yang adil, merata dan seimbang". Dengan demikian, melalui media komunitas, pemberdayaan masyarakat dan pemerataan pembangunan sampai ke pedesaan dapat tercapai, tanpa harus menimbulkan disintegrasi bangsa, di samping mencapai pemerataan informasi yang tepat secara adil atau proporsional.

Di lain pihak, pengakuan dunia internasional tentang manfaat radio komunitas sudah banyak dikaji. Sebagai perbandingan keberadaan media komunitas, khususnya radio siaran, data dari internet menunjukkan bahwa di beberapa negara berkembang, media komunitas ini sudah diakui memiliki nilai manfaat yang cukup tinggi. Media komunitas itu sendiri baru berkembang pada sekitar tahun 90-an di Indonesia, setelah sekian lama (tahun 70-an), beberapa pedesaan di beberapa negara sudah dimanfaatkan sebagai media pendidikan dan media pembangunan. Sebagai 
perbandingan, Swedia memiliki lebih dari 2000 radio komunitas, Denmark 300 radio yang memberi akses kepada 96\% dari total populasi; sedangkan di Amerika Serikat, tahun 2002, memiliki 2216 radio FM pendidikan dan 2396 Low Power TV yang digolongkan pada penyiaran publik dan komunitas. (Fraser \& Estrada, 2001)

Sistem media massa ini dianggap tepat/relevan untuk menggambarkan fenomena di Indonesia karena sesuai dengan latarbelakang kelahiran sistem ini yang digambarkan oleh McQuail. Pertama, merupakan suatu reaksi terhadap pola komersialisasi. Fenomena menunjukkan bahwa belanja iklan dari kalangan industri untuk menggunakan berbagai media massa dalam memasarkan hasil produksinya, sebagai kasus mencapai 5,8 trilyun rupiah per bulan. Sebuah hasil penelitian juga mengemukakan bahwa untuk surat kabar, porsi iklannya (dalam berbagai bentuk) antara $20-40 \%$, untuk surat kabar $20-35 \%$, majalah $20-40 \%$ Televisi swasta antara $20-45 \%$, radio swasta antara 20-40\%. (BIKN, 2000:103).

Sebab kedua, adanya monopoli pemilikan media. Marwah.D. Ibrahim (1994) mengemukakan, media komunikasi Indonesia diwarnai berbagai ketimpangan. Masih ada istilah pers lemah pers kuat, pers maju dan pers berkembang, pers pusat dan pers daerah. Data PPPI 1989-1990 mencatat, bahwa 77,1\% anggaran iklan diserap oleh surat kabar yang kuat, maju dan berskala nasional; dan sisanya, 22,9\% diserap oleh surat kabar lainnya. Demikian pula dengan majalah, $87,2 \%$ oleh ibu kota dan sisanya $12,8 \%$ majalah daerah. Saat ini, banyak penerbitan yang sudah mapan, memperbesar ekspansi perusahaannya dengan menerbitkan media massa lainnya. Sebagai kasus Surat kabar Kompas memiliki sejumlah 'anak penerbitan', percetakan, toko buku, stasiun radio, stasiun televisi, dan lain-lain, sehingga menjadi sebuah kelompok bisnis raksasa (konglomerasi).

Ketiga, sistem ini muncul karena adanya sentralisme dan birokrasi lembaga-lembaga siaran publik. Berdasarkan data empiris, tampak nyata bahwa sistem komunikasi politik serta sistem ekonomi dan bisnis di Indonesia masih diwarnai "Jakarta sentris". Data empiris menunjukkan, dari
700 penerbitan dengan tiras sekitar 15 juta, $71,10 \%$ terbit di Jakarta. Demikian pula dari 4.457 wartawan anggota PWI, 1.079 bertugas di Jakarta. (Atmakusumah, 2000). Berdasarkan kondisi fisik tersebut, jelas tampak bahwa komunikasi di Indonesia terkesan "urban bias", yaitu informasi yang tampak melalui media massa didominasi oleh kalangan elit, kaum profesional, birokrat, serta memperlihatkan kegemerlapan kota dan glamournya para selebritis.

Dengan demikian, penyediaan sarana berdiskusi secara mendalam atas persoalanpersoalan besar bangsa tidak secara terpusat mutlak perlu adanya. Secara lokal, memberi kesempatan berkomunikasi secara utuh pada masyarakat mayoritas yang nonelit, atas berbagai persoalan, seperti bantuan modal dari pemerintah, kegagalan panen, lahan yang kritis, perusakan sumber daya alam dan bencana alam, kesempatan kerja, urbanisasi, tidak adanya infrastruktur yang memadai, kesulitan transportasi, serta keprihatinan dan ketidakberdayaan masyarakat yang selama ini dirasakan oleh umumnya masyarakat di pedesaan.

\subsection{Identifikasi dan Rumusan Masalah}

\subsubsection{Identifikasi Masalah}

Berdasarkan uraian di atas, maka permasalahan yang dapat diidentifikasi yaitu : "Bagaimana Keberadaan, Peran dan Fungsi Radio Komunitas sebagai Eskalasi Demokratisasi Komunikasi pada Komunitas Pedesaan di Jawa Barat?"

\subsubsection{Rumusan Masalah}

(1) Bagaimana gambaran keberadaan, peran dan fungsi Radio Komunitas di Pedesaan serta mengapa para warga mendirikan Radio komunitas?

(2) Bagaimana proses komunikasi publik di pedesaan dan karakteristik perilaku komunikasi warga melalui radio komunitas?

(3) Apakah yang menjadi faktor-faktor penghambat dan pendukung, demokratisasi komunikasi pada komunitas pedesaan? 
(4) Bagaimana eskalasi (peningkatan) pemahaman, kesadaran, dan keterampilan untuk menghimpun, mengolah, mengkemas dan menyampaikan informasi pada warga komunitas pedesaan yang telah memiliki radio komunitas?

\subsection{Maksud dan Tujuan Penelitian}

Maksud dilaksanakannya penelitian ini adalah untuk menggambarkan, menganalisis, dan menginterpretasikan keberadaan media komunitas, khususnya radio pada suatu komunitas pedesaan, serta untuk menemukan eskalasi (peningkatan) demokratisasi komunikasi pada komunitas pedesaan.

Adapun tujuan penelitian ini secara utama memperoleh data dan informasi tentang keberadaan (eksistensi) radio komunitas serta mengkaji karakteristik dan perilaku berkomunikasi warga komunitas pedesaan. Tujuan lain adalah menemukan faktor-faktor penghambat dan pendukung demokratisasi komunikasi yang akan dikaji melalui eskalasi pemahaman, kesadaran, keterampilan untuk memperoleh atau menghimpun, mengolah dan menyampaikan informasi atau pendapat anggota komunitas pedesaan.

\subsection{Kerangka Pemikiran}

Kerangka pemikiran yang digunakan peneliti sebagai berikut. Pertama penelitian ini berusaha meninjau bagaimana sistem atau proses komunikasi yang berlangsung dalam komunitas pedesaan, untuk teori yang digunakan dari perspektif sosiologi komunikasi melalui struktural-fungsional. Kedua, digunakan teori sistem komunikasi bermedia, teori transformasi masyarakat dari Habermas dan teori demokrasi dari Huntington. Adapun untuk mengkaji penyelenggaraan radio komunitas, digunakan teori-teori yang sifatnya aplikatif.

\section{Tinjauan Pustaka}

\subsection{Konsep dan Perkembangan Radio Komunitas}

Selama dua dasa warsa terakhir, Unesco telah mendanai sejumlah penelitian dan telah diterbitkan dalam bentuk risalah dengan tema media komunitas. Judul risalah pertama adalah : "Akses: beberapa Model dari Dunia Barat mengenai Media Komunitas", ditulis Frances Berrigan terbit tahun 1977; kemudian topik yang diperluas ke negara-negara berkembang dalam penelitian :"Komunikasi Komunitas - Peran Media Komunitas dalam Pembangunan", dalam peneliti yang sama tahun 1981. Risalah selanjutnya disusun oleh Peter Lewis yang menyiapkan penelitian UNESCO dengan judul: "Media untuk penduduk kota" tahun 1984.

Dalam era globalisasi informasi yang melanda negara-negara di dunia, muncul kecenderungan adanya perusahaan-perusahaan media komunikasi yang lebih mementingkan aspek komersial, termasuk di Indonesia. Fenomena majalah, surat kabar, serta program acara televisi asing (Amerika, Eropa, Australia) yang diadopsi di Indonesia kian marak, terutama jenis acara/media hiburan. Walaupun hasil-hasil riset terhadap khalayak pemirsa, ternyata mereka lebih memilih menonton program yang berorientasi pada budaya masingmasing dibandingkan dengan program impor dari negara lain.

Untuk itu, langkah logis dalam mencapai perluasan dan pemerataan kebutuhan informasi yang tepat atau dengan kata lain, mencapai demokratisasi media hingga ke tingkat komunitas adalah melalui radio yang daya jangkaunya luas, relatif murah dengan teknologi penyiaran yang sederhana. Namun, banyak pihak media kapitalis yang tidak rela keuntungannya digugat; kecurigaan George Orwe tertuang dalam bukunya, Nineteen Eighty Four (1984) akan adanya gerakan sistimatis pihak tertentu menuju globalisasi media.

"Orwe sangat peduli mengenai gerakan kaum sosialis tentang era industri, tapi dia juga memperingatkan bahwa ada pengambilalihan masyarakat oleh sebuah kekuatan politis demokratis yang sedang mengalami penurunan, oleh gerakan-gerakan yang sangat industrialis. Dan oleh suatu tujuan akhir yang mudah untuk menuju globalisasi media”(Arnaldo, 1998: 2). 
Kaum industri media, jelas tidak sepakat, jika masyarakat menjadi sadar bahwa penyiaran acaraacara yang menawarkan "mimpi" itu sebetulnya bukan untuk mereka. Sehingga pada mulanya dengan kemunculan media komunitas, ada sikap menentang yang datang dari sebagian besar media komersial.

\subsection{Peran dan Fungsi Media Komunitas}

Secara umum Peran dan fungsi Media Komunitas merujuk pada tugas atau kewajiban yang harus dijalankan oleh lembaga media komunikasi dan informasi di tengah-tengah komunitasnya. Selain itu fungsi media komunitas juga merujuk pada manfaat yang dapat dirasakan atau diperoleh oleh semua pihak yang terlibat; namun yang paling dominan harus dirasakan manfaat sebesar-besarnya bagi mayoritas warga komunitas setempat.

Menurut The National Community Radio Forum (NCRF), yaitu forum radio komunitas yang sudah memiliki 54 negara sebagai anggotanya di dunia, mengemukakan manfaat radio komunitas adalah:

(1) Berpartisipasi. Merupakan kekuatan bagi komunitas untuk membuka pintu perubahan kehidupan komunitas

(2) Melayani informasi di segala sektor kehidupan komunitas

(3) Mempromosikan dan merefleksikan budaya, karakter, dan identitas lokal/komunitasnya.

(4) Meningkatkan akses untuk penyebaran informasi secara lisan.

(5) Merupakan bentuk tanggungjawab sosial atas kebutuhan komunitasnya.

(6) Berperan penting sebagai pemberi kekuatan bagi kaum yang terpinggirkan

(7) Dan lainnya ( http://www.sn.apc.org/ncrf/report/committee.htm).

Pertumbuhan radio komunitas, dari waktu ke waktu terus meningkat. Namun, keberadan media tersebut dibatasi oleh frekuensi yang tersedia. Terdapat kekhawatiran dari pihak-pihak tertentu dengan maraknya radio komunitas di Indonesia, di antarnya radio swasta yang merasa "terganggu" karena khalayak pendengarnya beralih kepada ra- dio komunitas. Selain itu, eksistensi penyiaran komunitas dianggap sebagai pemicu terjadinya konflik yang bernuansa SARA ( Suku Agama, Ras dan Antar Golongan), serta pemborosan spektrum radio. Adapun mengenai pemborosan frekuensi, hasil analisis pakar dari ITB, Onno W.Purbo, bila pemerintah merelakan sekitar 5\% saja gelombang yang ada untuk radio komunitas, maka ratusan radio komunitas yang bisa didirikan dan jutaan penduduk bisa berbicara tanpa harus ke DPRD. Ia tidak setuju dengan kekhawatiran, bahwa keberadaan penyiaran komunitas hanya akan menghamburkan frekuensi.

Demokratisasi komunikasi melalui media komunitas, merupakan aktivitas yang melibatkan sebanyak mungkin warganya, dalam proses memperoleh atau mengumpulkan bahan dan informasi, pengolahan, penyajian serta penyebarluasan informasi. Secara standar teoretis jurnalistik, umumnya memiliki karakter yang sama di antara berbagai bentuk media, baik cetak maupun elektronik. Namun, ditinjau dari karakteristik radio komunitas, komponen kepemilikan, tujuan dan fungsi, sasaran khalayak, mewarnai proses jurnalistik yang berbeda dengan media massa komersial.

\section{3 "Civic Journalism"}

Rosen dalam Yoon \& Park (2001:341) mengemukakan gagasannya tentang jurnalistik publik sebagai berikut: "Jurnalistik publik adalah suatu model peliputan berita yang bertujuan sesuai dengan misi negara yakni mendorong kehidupan publik/warga negaranya menuju kesejahteraan dan mencari konsensus untuk memecahkan permasalahan di masyarakat." Tujuan utama kegiatan jurnalistik ini adalah untuk mencari aspekaspek yang selama ini terlupakan atau tersingkirkan di dunia pers orang Amerika. Sebetulnya tradisi ini di Indonesia sudah lama dikenal dengan nama "jurnalistik pembangunan"; oleh karena pada kegiatan jurnalistik ini menekankan pertumbuhan motivasi dari khalayak penerimanya untuk memperbaiki, memajukan atau mensejahterakan kehidupan mereka, baik di bidang ekonomi, politik, hukum, kesehatan dan bidang lainnya. 
Rosen (2001) mendefinisikan Peran Civic Journalism sebagai "perbaikan kapasitas dialog publik, menolong orang-orang untuk mencari pemecahan masalah".

(1) Civic Journalism menjalankan aktivitas jurnalistik dengan menetapkan sebelumnya tentang efek/akhir tulisan, menjaga kehidupan publik dan demokrasi. Hal ini tidak cukup untuk mendidik orang-orang, perlu mengikutsertakan orang-orang dalam informasi harus menjadi tujuan.

(2) Civic Journalism mencakup realisasi dari partisipasi para jurnalis, tidak hanya sebagai penonton, dalam kehidupan publik siapa pun memperoleh pengaruh yang timbal balik dalam membangun identitas bangsanya.

(3) Pada realitas aktivitas jurnalistik, jurnalis dan warga negara memiliki sudut pandang yang berbeda. Civic Journalism mengacu pada apa yang dipikirkan oleh khalayak sebagai suatu kumpulan warga negara, bukan hanya sebagai konsumen media. Rosen melihat warga negara merupakan pusat "aktor dan orang yang berdiskusi" dalam kehidupan publik. Notasi atau dugaan ini ketertutupan hubungan antara warga negara dengan konsep komunitarian di mana didasari oleh penciptaan dialog publik untuk memproduksi makna, pemahaman, dan hubungan.

\subsection{Demokratisasi Komunikasi}

Dalam konteks penelitian ini, komunikasi dalam demokrasi berkaitan dengan bagaimana warga negara dapat merealisasikan atau mewujudkan kewarganegaraannya. Mungkin dalam hal ini perlu kita rujuk konsep kewarganegaraan yang dikembangkan oleh T. H. Marshall.

Menurut Marshall (seperti dikutip oleh Murdock dan Golding, 1989: 18-34), ada paling tidak tiga dimensi kewarganegaraan: sipil, politik dan sosial. Hak-hak sipil berkaitan dengan kebebasan gerak individual dalam ruang masyarakat sipil (civil society). Termasuk kedalamnya, antara lain, kebebasan untuk berbicara, kebebasan berpikir dan beragama, kebebasan untuk bergerak dan berasosiasi, serta kebebasan untuk memiliki dan mengatur kepemilikannya. Hak-hak politik berkenaan dengan kondisi-kondisi yang menjamin orang untuk berpartisipasi dalam penggunaan kekuatan politik dengan menguasai lembaga negara, memilih anggota-anggota dewan perwakilan yang merumuskan kebijakan dan mengeluarkan berbagai aturan serta dengan melibatkan diri dalam pelaksanaan hukum melalui keanggotaan sebagai 'juri'.

Warga negara, dengan demikian, diasumsikan sebagai seorang yang berhak berpartisipasi dalam proses politik. Hanya dengan demikian warga negara memberikan legitimasi bagi pemerintah untuk memerintahnya. Hak sosial berkaitan dengan hak setiap warga negara untuk memperoleh jaminan standar dasar kehidupan dan kesejateraan. Ini biasanya direalisasikan melalui pelembagaan negara kesejahteraan (welfare state).

Murdock dan Golding memberi interpretasi baru terhadap hak ketiga ini. Menurut mereka, warga negara juga berhak untuk memperolah akses universal pada fasilitas komunikasi dan informasi. Karena hal ini menyangkut kondisi-kondisi yang memungkinkan rakyat mewujudkan hak-hak kewarganegaraan mereka yang lainnya seperti hak untuk berpartisipasi dalam kehidupan politik. Dengan demikian, hak untuk akses terhadap komunikasi dan informasi menjadi prasyarat dasar bagi perealisasian kewarganegaraan.

Lebih lanjut, Murdock dan Golding (1989:1834) melihat adanya tiga jenis hubungan antara komunikasi dan kewarganegaraan. Pertama, orang harus punya akses pada informasi, nasihat-nasihat dan analisis yang memungkinkan mereka untuk mengetahui hak-hak mereka di ruang lain dan memungkinkan mereka untuk mencapai hak ini secara efektif. Kedua, mereka harus punya akses pada kemungkinan jangkauan atau cakupan informasi yang paling luas, interpretasi, dan debat pada bidang-bidang yang melibatkan pilihan politis dan mereka mampu menggunakan fasilitas komunikasi dalam usaha untuk melakukan kritik, mobilisasi oposisi dan menawarkan alternatif tindakan. Ketiga, mereka harus mampu mengetahui diri mereka dan aspirasi mereka dalam beragam 
perwakilan yang ditawarkan dalam sektor komunikasi yang penting dan mampu menyumbang pengembangan perwakilanperwakilan tersebut.

Di sisi lain, Calhoun dan Habermas (dalam Hidayat 2003:vii) berpendapat bahwa : "Hak informasi masyarakat seperti dalam gagasan $\mathrm{Pub}$ lic Sphere adalah hak untuk mencari, memakai, menggunakan, membuat secara bebas, informasi apa pun yang diinginkan, dalam sebuah ruang publik yang terbuka di mana masing-masing kedudukan pihak - pihak tersebut adalah setara". Berdasarkan hubungan tersebut, Murdock dan Golding berpendapat bahwa sistem komunikasi dan informasi harus memiliki dua ciri utama. Pada tingkat produksi, ia harus menawarkan keberagaman dan menyediakan umpan balik dan kemungkinan partisipasi bagi khalayak. Pada tingkat konsumsi ia harus dapat menjamin akses universal orang terhadap lembaga komunikasi terlepas dari penghasilan dan tempat tinggal orang. Persoalannya, pengorganisasian institusi komunikasi model mana yang paling sempurna bagi perwujudan kewarganegaraan secara maksimal

\section{Objek dan Metodologi Penelitian}

Sebagai objek utama yang diteliti adalah radio komunitas di Jawa Barat, karena wilayah Jawa

Pola dan Karakteristik Perilaku Kom unikasi Publik

\begin{tabular}{|c|c|}
\hline Daerah Tertutup (Cisewu) & Daerah Terbuka ( Wanayasa) \\
\hline $\begin{array}{l}+ \text { Peran institusi formal hanya melibatkan } \\
\text { sekelompok elitltokoh masyarakat formal, informal, } \\
\text { belum menarik partisipasi warga secara keseluruhan }\end{array}$ & $\begin{array}{l}+ \text { Tersedianya berbagai organisasi massa sebagai } \\
\text { institusi publik dimana semua orang dapat mengakses } \\
\text { aktivitas didalammya. }\end{array}$ \\
\hline $\begin{array}{l}\text { + Kepemimpinan camat dan kepala desa masih } \\
\text { dominan, warga merasa segan untuk mendekat. }\end{array}$ & $\begin{array}{l}\text { + Keakraban antara warga biasa dengan para pimpinan } \\
\text { formal maupun informal berlangsung dengan } \\
\text { harmonis }\end{array}$ \\
\hline $\begin{array}{ccc}+ \text { Sumber kekuasaan tokoh agama, } & \begin{array}{l}\text { guru-guru, } \\
\text { pemeintah }\end{array} \\
\text { sebagian } & \text { pejabat } & \text { a }\end{array}$ & $\begin{array}{l}\text { + Sumber kekuasaan: Budayawan, pejabat pemerintah, } \\
\text { pengusaha. }\end{array}$ \\
\hline $\begin{array}{l}\text { + Masih nampak ada jenjang/gap di antara kelompok } \\
\text { ekonomi, pendidikan tinggi dengan yang rendah }\end{array}$ & $\begin{array}{l}\text { + Masih ada perbedaan, walaupun sangat tipis antara } \\
\text { kelompok-kelompok dalarn komunitas Wanayasa. }\end{array}$ \\
\hline $\begin{array}{l}\text { + Rendahnya kepemilikan informasi yang bersumber } \\
\text { dan semua media massa, kecuali stasiun televisi } \\
\text { tertentu melalui parabola digital yang hanya sedikit. }\end{array}$ & $\begin{array}{l}+ \text { Akses Informasi kepemilikan informasi bersumber } \\
\text { dan semua media massa, terutama koran ibu kota; } \\
\text { hampir semua stasiun televisi (TVRI dan Swasta) } \\
\text { tertangkap. }\end{array}$ \\
\hline $\begin{array}{l}+ \text { Pola interaksi sosial warga pedagang dengan } \\
\text { petani, siswa pelajar dengan guru, pemerintah/tokoh } \\
\text { dengan warga untuk pembangunan desa, partai } \\
\text { dengan warga untuk memperoleh dukungan }\end{array}$ & $\begin{array}{l}\text { + Pola interaksi sosial budayawan dengan budayawan, } \\
\text { sesama PNS dan pensiunan, pemerintah/tokoh dengan } \\
\text { warga untuk pembangunan desa, partai dengan warga. }\end{array}$ \\
\hline + Aktivitas sosial guru-murid; pemda-warga & + Aktivitas sosial : lebih Egaliter \\
\hline+ Aktivitas politik partai dan warga & $\begin{array}{l}\text { + Aktivitas politik partai dan warga; diantara warga } \\
\text { sudah bisa mengenyampingkan latar belakang masing- } \\
\text { masing partai dalam menyelesaikan kepentingan } \\
\text { publik. }\end{array}$ \\
\hline
\end{tabular}


Barat merupakan salah satu propinsi yang paling banyak memiliki radio komunitas. Adapun penetapan Kecamatan Cisewu Kabupaten Garut Selatan dan Kecamatan Wanayasa Kabupaten Purwakarta, dilatarbelakangi pertimbanganpertimbangan penelitian, yaitu mewakili daerah tertutup dan daerah terbuka. Penelitian ini menggunakan metode penelitian kualitatif dengan model penelitian etnografi. Sebagai pertimbangannya bahwa fokus penelitian ini adalah menyelidiki cara-cara berkomunikasi melalui media, yang telah dipolakan dan diorganisasikan dalam sebuah sistem komunikasi pada suatu komunitas; di mana cara dan pola tersebut berinteraksi dengan seluruh sistem budaya yang ada di dalamnya.

Troike (1982) menegaskan tentang fokus etnografi komunikasi adalah : “... the way communication within it is patterned and organized as systems of communicative events, and the ways in which these interact with all other systems of culture" (Troike, $1982: 3)$.

\section{Pembahasan}

Di saat reformasi tahun 1998 menimbulkan gerakan sosial yang menuntut keterbukaan,

\section{Kendala/Hambatan Penyelenggaraan Radio Komunitas Menuju Proses Demokratisasi Komunikasi}

\begin{tabular}{|c|c|}
\hline Wilay ah Tertutup (C isewu) & Wilayah Terbuka (Wanayasa) \\
\hline $\begin{array}{l}\text { 1. Kurangnya sarana dan prasarana yang baik } \\
\text { (kesekretariatan, bahan penunjang dan } \\
\text { infrastruktur) tenyata dapat menghambat } \\
\text { terhadap jalannya segala program yang akan } \\
\text { dilaksanakan. }\end{array}$ & $\begin{array}{l}\text { 1. } \\
\text { Kurangnya sarana dan prasarana yang baik } \\
\text { (kesekretariatan, bahan penunjang seperti } \\
\text { ATK, dan yang lainnya) tenyata dapat } \\
\text { menghambat terhadap jalannya segala } \\
\text { program yang akan dilaksanakan. }\end{array}$ \\
\hline $\begin{array}{l}\text { 2. Mininmya parapejabat formal/generasi tua } \\
\text { yang ingin turut berkiprah dalam } \\
\text { mengelola lembaga penyiaran. }\end{array}$ & $\begin{array}{l}\text { 2. Keterbatasan Sumber Daya Manusia dalam } \\
\text { pengelolaan lembaga (manajerial skill). }\end{array}$ \\
\hline $\begin{array}{l}\text { 3. Pemahaman tentang peran fungsi serta posisi } \\
\text { DPK dan para pengurus maupun anggota } \\
\text { komunitas masih kurang. }\end{array}$ & $\begin{array}{l}\text { 3. Kurangnya pemahaman tentang peran fungsi } \\
\text { pengelolaan media informasi dan warga } \\
\text { komunitas. }\end{array}$ \\
\hline $\begin{array}{l}\text { 4. Pengembangan radio yang telah ada sulit } \\
\text { dilakukan karena keterbatasan berbagai } \\
\text { sumberdaya secara internal. }\end{array}$ & $\begin{array}{l}\text { 4. Pengembangan profesionalitas radio sulit } \\
\text { dilakukan karena tidak ada Jaringan kerja } \\
\text { (networking) }\end{array}$ \\
\hline $\begin{array}{l}\text { K. Keadaan lokasi daerah yang berelief } \\
\text { bergunung-gunung menyulitkan terhadap } \\
\text { koordinasi antar radio apalagi ditengarai } \\
\text { dengan terbatasnya sarana transportasi dan } \\
\text { alat komunikasi. }\end{array}$ & $\begin{array}{l}\text { 5. Tidak adanya sumber pemasukan dana yang } \\
\text { tetap / berkesinambungan, sehingga sampai } \\
\text { saat ini keadaan kas anggaran tidak menentu. }\end{array}$ \\
\hline $\begin{array}{l}\text { 6. Tidak adanya sumber pemasukan dana yang } \\
\text { tetap/rutin, sehingga sampai sat ini anggaran } \\
\text { tidak menentu. }\end{array}$ & $\begin{array}{l}\text { 6. Belum adanya lembaga yang bisa diajak } \\
\text { kerjasama secara rutin. }\end{array}$ \\
\hline $\begin{array}{l}\text { 7. Belum adanya pihak pendamping/LSM untuk } \\
\text { bekerja sama. }\end{array}$ & $\begin{array}{l}\text { 7. Idealisme pengelola belum tentu sama dengan } \\
\text { para perintisnya dalam menjalankan visi misi } \\
\text { radio komunitas. }\end{array}$ \\
\hline
\end{tabular}




\section{Pemahaman \& Kesadaran Warga tentang Hak Informasi Publik}

\begin{tabular}{|c|c|}
\hline Wilayah Tertutup (Cisewu) & Wilayah Terbuka (Wanayasa) \\
\hline Pimpinan formal \& Informal & Pimpinan formal \& Informal \\
\hline $\begin{array}{l}\text { 1. Warga perlu diberi informasi atau penjelasan } \\
\text { tentang program pemerintah. }\end{array}$ & $\begin{array}{l}\text { 1. Warga perlu diberi informasi tentang program } \\
\text { pemerintah, tetapi dengan dugaan bahwa } \\
\text { merekajuga bisa mencari informasi sendiri. }\end{array}$ \\
\hline $\begin{array}{l}\text { 2. sebagian besar warga perlu dimotivasi, } \\
\text { dimobilisasi untuk beraktivitas dalam kegiatan } \\
\text { publik, (termasuk komunikasi). }\end{array}$ & $\begin{array}{l}\text { 2. Warga memiliki inisiatif untuk saling bertukar } \\
\text { informasi, bahkan untuk mengkritik pejabat/tokoh } \\
\text { sekalipun }\end{array}$ \\
\hline $\begin{array}{l}\text { 3. Radio komunitas bukan merupakan saluran } \\
\text { informasi yang paling efektif. }\end{array}$ & $\begin{array}{l}\text { 3. Radio komunitas dimanfaatkan untuk berinteraksi } \\
\text { antar warga dan memperluas informasi }\end{array}$ \\
\hline $\begin{array}{l}\text { 4. Interaksi melalui forum komunikasi informal } \\
\text { tatap muka, dipilih karena belum menyadari } \\
\text { kekuatan radio komunitas. }\end{array}$ & $\begin{array}{l}\text { 4. Interaksi komunikasi berlangsung paralel } \\
\text { komunikasi melalui komunitas. }\end{array}$ \\
\hline Warga Biasa & Warga Biasa \\
\hline $\begin{array}{l}\text { 1. Informasi diperlukan dan dapat dimanfaatkan } \\
\text { selama ada keterkaitan dengan kehidupan } \\
\text { sehari-harinya }\end{array}$ & $\begin{array}{l}\text { 1. Warga punya motivasi untuk mengetahui } \\
\text { berbagal informasi tentang apapun. }\end{array}$ \\
\hline $\begin{array}{l}\text { 2. Informasi akan diolah, diproses disampaikan } \\
\text { secara personal kepada lingkungan terdekatnya, } \\
\text { bukan untuk disebarkan sebagai konsumsi } \\
\text { umum }\end{array}$ & $\begin{array}{l}\text { 2. Pengalaman dan pengetahuan personal akan } \\
\text { diolah untuk disebarkan melalui radio komurntas } \\
\text { sebagai konsumsi publik dan ditanggapi secara } \\
\text { kumulatif, sehingga menjadi 'opini publik' }\end{array}$ \\
\hline $\begin{array}{l}\text { 3. Belum mampu mengkemas kritikan pada } \\
\text { penguasa karena ada hambatan psikologis dan } \\
\text { budaya. (heurin ku letah, Malapah gedang) }\end{array}$ & $\begin{array}{l}\text { 3. Penyampaian informasi yang kontroversial } \\
\text { dikemas dan disampaikan secara (sindiran- } \\
\text { sindiran dan sedikit demi sedikit). }\end{array}$ \\
\hline
\end{tabular}

Berkurangnya dominasi elite dan mengurangi kekuasaan negara, juga memunculkan berkurangnya kredibilitas dan kepercayaan publik, ketidakpuasan masyarakat terhadap pemerintah. Gerakan sosial ini, terwujud pula pada semangat masyarakat dalam berkomunikasi dan menggunakan media informasi yang dalam konteks kontradiksi, memuncukan tantangan yang berarti untuk menjamin demokrasi dalam global.
Gambaran tentang eksistensi, termasuk peran dan fungsi radio komunitas bagi masing-masing wilayah, satu dengan yang lain berbeda. Hal ini berkaitan dengan pola dan karakteristik perilaku komunikasi warga dalam sebuah komunitas.

Pembahasan ini digambarkan dalam bentuk model, sehingga tampak secara utuh gambaran realitas keberadaan radio komunitas yang terkait dengan aspek pendukung, atau penghambat demokratisasi komunikasi di pedesaan. 
Aplikasi Demokratisasi Komunikasi di Pedesaan

\begin{tabular}{|l|c|c|c|c|c|c|}
\hline \multirow{2}{*}{ KOMPONEN } & \multicolumn{2}{|c|}{ Pemahaman } & \multicolumn{2}{c|}{ Kesadaran } & \multicolumn{2}{c|}{ Keterampilan } \\
\cline { 2 - 7 } & Tertutup & Terbuka & Tertutup & Terbuka & Tertutup & Terbuka \\
\hline Menerima/mencari informasi & ST & ST & BT & ST & BT & ST \\
\hline $\begin{array}{l}\text { Menghimpun/memakai } \\
\text { Informasi }\end{array}$ & BT & BT & BT & ST & BT & ST \\
\hline $\begin{array}{l}\text { Mengolah/Membuat } \\
\text { informasi }\end{array}$ & BT & ST & BT & BT & BT & BT \\
\hline $\begin{array}{l}\text { Menyampaikan/ Mengemas } \\
\text { Informasi }\end{array}$ & BT & ST & BT & ST & BT & ST \\
\hline
\end{tabular}

Keterangan $: \mathrm{BT}=$ Belum Tercapai $\quad \mathrm{ST}=$ Sudah Tercapai,

\section{Kesimpulan dan Saran}

\subsection{Kesimpulan}

(1) Keberadaan radio komunitas merupakan media komunikasi baru dalam komunitas yang bersifat interaktif, sederhana, dan memiliki kekhasan, di mana prosesnya berada di antara komunikasi melalui media massa dan komunikasi antarpersona. Karakteristik radio komunitas cenderung merepresentasikan kepentingan berbagai kelompok dalam komunitas dan merupakan wujud resistensi terhadap dominasi informasi penyiaran komersial yang sudah ada selama ini. Ketidakpuasan warga komunitas pedesaan yang diabaikan kepentingan dan kebutuhan informasinya, merupakan latar belakang didirikannya radio komunitas yang berprinsip "dari warga-oleh warga-untuk warga".

(2) Di pedesaan radio komunitas muncul serentak secara signifikan karena ada dorongan perubahan politik di Indonesia, yaitu ketika kondisi keterbukaan pada era reformasi. Tersedianya berbagai forum dan saluran komunikasi di "ruang publik", ternyata memberi semangat dan kesadaran kepada warga komunitas pedesaan tentang hak mereka untuk mengemukakan pendapatnya. Namun, kondisi ini tidak disertai dengan pembelajaran warga lebih profesional dalam berkomunikasi.

(3) Peran dan fungsi radio komunitas di pedesaan belum optimal sebagai media percepatan dan perluasan informasi antar warga serta dalam meningkatkan intensitas komunikasi interaktif secara kolektif. Oleh karena dipengaruhi oleh tradisi-tradisi komunikasi yang sudah mapan dalam bentuk informal, lebih bersifat topdown untuk wilayah tertutup dan bersifat horisontal untuk wilayah terbuka.

(4) Penyelenggaraan radio komunitas secara 
teknis, manajerial, pemanfaatan sumber daya belum optimal, karena terdapat berbagai hambatan/kendala. Pada wilayah tertutup, kendala utamanya aspek keterisolasian fisik, akses informasi rendah dan kondisi SDM khususnya pada budaya paternalistik. Kendala dalam penyelenggaraan radio komunitas ini pada gilirannya akan berakibat pada proses eskalasi demokratisasi komunikasi.

(5) Faktor tradisi berkomunikasi secara tatap muka, bersifat informal dalam kehidupan sehari-hari, masih mendominasi perilaku komunikasi warga desa dan ini mempengaruhi proses berlangsungnya komunikasi publik. Intensitas, relevansi komunikasi dan interaksi antarwarga melalui radio komunitas lebih mencerminkan kondisi pola komunikasi dan interaksi warga komunitas sehari-hari.

(6) Demokratisasi komunikasi di wilayah pedesaan yang diukur dari pemahaman, kesadaran, dan penerapan aturan (regulasi) pendirian radio komunitas, prosedural, dan perilaku penyelenggaran siaran, serta pemberian kesempatan yang sama bagi warga untuk berkomunikasi; umumnya lebih banyak ditemui di daerah terbuka dan kalangan pemuda dibandingkan di daerah tertutup dan kalangan orang tua.

(7) Keberadaan radio komunitas di pedesaan lebih sebagai inisiator pada wilayah tertutup dan sebagai akselerator pada wilayah terbuka bagi eskalasi demokratisasi komunikasi.

\subsection{Saran}

(1) Disarankan ada suatu aturan dari pemerintah yang mengalokasikan kepentingan warga komunitas pedesaan untuk memeroleh hak informasi yang sama dengan warga komunitas perkotaan, baik dari segi infrastruktur secara kuantitas dan kualitas maupun program pembangunan komunikasi dan informasi lainnya.

(2) Tidak adanya tanggung jawab sosial dari radio komersial terhadap kepentingan publik dalam arti pemenuhan kebutuhan informasi yang benar dan cocok, secara merata bagi warga pedesaan; yang dicerminkan melalui acara-acara yang hanya berorientasi pasar dan menjangkau wilayah publik yang mampu secara ekonomi (perkotaan) saja. Disarankan ada peraturan pemerintah daerah yang mengalokasikan sejumlah sumber daya yang dimiliki radio komersial untuk dihibahkan pada radio komunitas.

(3) Disarankan agar ada persiapan yang cukup matang, baik dari teknis peralatan maupun non teknis sperti pemahaman dan keterampilan menyusun content/program acara siaran, teknik manajerial bagi para calon pengelola radiokomunitas. Hal ini karena radio komunitas saat ini banyak didirikan "hanya" dengan modal semangat.

(4) Disarankan agar ada aktivitas inisiasi dari lembaga pemerintah terkait dan LSM(lembaga Swadaya Masyarakat) yang concern terhadap penguatan masyarakat di kalangan grass root, akan hak-hak komunikasi dan informasi, di tengah-tengah dominasi industri penyiaran yang bersifat kapitalis, melalui forum-forum latihan, diskusi, magang, dan pembelajaran dalam arti luas di setiap peluang yang tersedia

(5) Sebaiknya, bagi asosiasi Jaringan Radio Komunitas (JRK) yang ada di Jawa Barat, lebih ditingkatkan intensitasnya untuk membimbing pada anggotanya dalam rangka peningkatan pemahaman, kesadaran, serta keterampilan jurnalisme publik yang bersifat interaktif. Di samping itu, memberi kesempatan melalui berbagai forum untuk sharing pengalaman di bidang penyelenggaraan radio dan pengelolaan sumber daya (keuangan, SDM, Teknis) yang sangat terbatas, namun bisa menyajikan program acara yang berkualitas.

(6) Kemampuan mengelola content, materi siaran yang sesuai dengan kebutuhan warga komunitas dan bermanfaat, serta memiliki daya tarik dan membangkitkan partisipasi dari warga memerlukan perencanaan dan persiapan yang tepat. Untuk itu disarankan agar ada pelatihan dan aktivitas edukasi bagi warga yang berminat mengelola radio komunitas dari 
berbagai kalangan, baik praktisi berpengalaman maupun dari akademisi perguruan tinggi yang terkait.

\section{Daftar Pustaka}

Astraatmadja. Atmakusumah. 2000, "Local Community Papers and Radio Stations egional TV Stations could help the Poor" Presentation at The Ramon Magsaysay wardees eeting Taipe, Taiwan.

Badan Informasi dan Komunikasi Nasional (BIKN). 2000. Karakteristik Media dan Khalayak Layanan. Laporan Penelitian. Jakarta.

Creswell, John.W., 1994. Research Design, Quantitative \& Qualitative Approaches, terjemahan, Nurkhabibah, KIK Press Jakarta, 2002.

1998. Qualitative inquiry and Research Design Choosing Among Five Traditions. London. New Delhi: Sage Publications.

Combine Resources Institution (CR1), "Perkembangan Radio Komunitas di Indonesia dalam Konteks Makro", Makalah seminar hasil penelitian, Jakarta.

Fraser, Cohn \& Sofia Restrepo Estrada. 2001. Buku Panduan Radio Komunitas. Penerjemah Tim Jaring line, Penyunting Tim Komunikasi UNESCO, Jakarta.
1993. Menuju Masyarakat Komunikatif, Ilmu, Masyarakat, Politik \& Postmodernisme menurut Jurgen Habermas. Yogyakarta: Penerbit Kanisius.

Huntington, Samuel P., \& Joan M. Nelson, 1984. Partisipasi Politik di Negara Berkembang. Jakarta: PT Sangkala Pulsar.

Ibrahim, Marwah Daud. 1994. Teknologi Emansipasi dan Transendensi, Wacana Peradaban dengan Visi Islam. Bandung: Mizan.

Lembaga Informasi Nasional (LIN). 2001. Pengembangan Informasi Umpan Balik Mengenai Layanan dan Aturan Pemerintah. Jakarta: Laporan Penelitian.

McQuail, Denis. 1987. Mass Communication Theory, Second Edition, Diterjemahkan Agus Dharma,\& Aminuddin Ramm, 1994. Jakarta: Penerbit Erlangga,

Murdock, G. \& Golding P. 1989. "Information Poverty and Political inequality: citizenship in the age of privatized communications." Journal Communication, 39 (3).

Yoon, Suk-Hong \& Park, Jae-Yung, 2001, “Attitudes of Korean Journalist and Journalism Educators toward Civic Journalism”. Korean Journal of Journalism \& Communication Studies, Special English Edition. 